\title{
Dual-release hydrocortisone treatment: glycometabolic profile and health-related quality of life
}

\author{
L M Mongioì, R A Condorelli, S La Vignera and A E Calogero \\ Department of Clinical and Experimental Medicine, University of Catania, Catania, Italy \\ Correspondence should be addressed to A E Calogero: acaloger@unict.it
}

\begin{abstract}
Objective: Adrenal insufficiency (AI) is a chronic condition associated with increased mortality and morbidity. The treatment of $\mathrm{Al}$ in the last years has been object of important changes due to the development of a dual-release preparation of hydrocortisone. It differs from previous therapeutic strategy as it contemplates a once-daily tablet that allows more closely mimicking the physiological circadian cortisol rhythm. The aim of the study was to evaluate the effects of dual-release hydrocortisone treatment on the glycometabolic profile and health-related quality of life of patients with Al.

Design and Methods: In this clinical open trial, we enrolled ten patients with primary $\mathrm{Al}(41 \pm 2.67$ years $)$ and nine patients with Al secondary to hypopituitarism (53.2 \pm 17.7 years). We evaluated the glycometabolic profile before and 3, 6, 9 and 12 months after dual-release hydrocortisone administration. We also evaluated health-related quality of life, estimated by the AddiQol questionnaire. The mean dose administered of dual-release hydrocortisone was $28.33 \pm 6.68 \mathrm{mg} / \mathrm{day}$.

Results: One female hypopituitary patient dropped out from the study. After 12 months of treatment, the mean dosage administered of dual-release hydrocortisone was significantly lower $(P<0.05)$ and all patients reported improved quality of life and well-being. The glycometabolic profile improved and the glycosylated hemoglobin decreased significantly in patients with primary Al $(6.25 \pm 0.2$ vs $5.35 \pm 0.17, P<0.05)$. In contrast, hypopituitary patients had worse glycometabolic profile and a trend toward hypertriglyceridemia.

Conclusions: Dual-release hydrocortisone treatment improved the quality of life of patients with $\mathrm{Al}$, and it allowed a decrease of cortisol dosage administered in the absence of side effects. The glycometabolic profile worsened in hypopituitary patients.
\end{abstract}

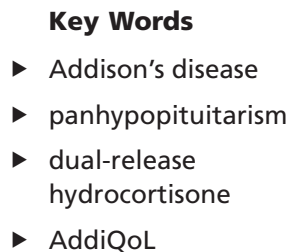

Endocrine Connections (2018) 7, 211-219

\section{Introduction}

Adrenal insufficiency (AI) is a disease caused by either primary adrenal failure (Addison's disease, over 90\% due to autoimmune adrenalitis) (1) or by hypothalamicpituitary impairment of the corticotropic axis alone or in combination with other anteropituitary hormone deficiency (CPHD) (2). This rare condition needs chronic glucocorticoid and, sometimes, mineralocorticoid administration. Despite replacement therapy, AI is characterized by high mortality rate compared to general population (3) and by an increased risk of comorbidity, especially cardiovascular diseases, obesity and glycometabolic alteration $(4,5,6,7)$.

$$
\begin{array}{lr}
\text { http://www.endocrineconnections.org } & \text { () } 2018 \text { The authors } \\
\text { https://doi.org/10.1530/EC-17-0368 } & \text { Published by Bioscientifica Ltd }
\end{array}
$$

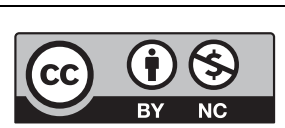


A 2013 consensus statement recommended administering as replacement therapy a daily hydrocortisone dose of $15-25 \mathrm{mg}$ (8). The conventional treatment involves a double or triple administration of glucocorticoid, thus causing a supraphysiological cortisol exposition. Recently, a new once-daily dual-release hydrocortisone formulation has been developed to improve pharmacokinetic and pharmacodynamic profiles as well as patient compliance (9).

The aim of the present study was to evaluate the effects of dual-release hydrocortisone treatment on the glycometabolic and lipid profiles of patients with primary or central AI. Another aim was to evaluate health-related quality of life of these subjects, assessed by self-administered questionnaire.

\section{Subjects and methods}

Since the prescription of dual-release hydrocortisone has been approved by the Italian drug agency, the ethical committee approval was not required. Anyhow, each patient who participated in this study was asked to sign a written informed consent. Different from previous studies, we included not only patients with known primary and secondary AI, but also newly diagnosed patients. The presence of severe comorbidities was instead considered an exclusion criterion. We enrolled nineteen patients who were divided into two groups: ten patients with primary AI (6 men and 4 women, mean age $41 \pm 2.67$ years) (Table 1 ) and 9 patients with AI secondary to hypopituitarism (6 men, 3 women, mean age 53.2 \pm 17.7 years) (Table 2 ).

Among these patients, 14 were already on glucocorticoid replacement therapy, while five (two patients with primary AI and three with hypopituitarism) were naïve, as with newly diagnosed disease (Tables 1 and 2). Hypopituitary patients were under replacement therapy according to the other hormonal axes deficiency (Table 2). Three of the enrolled patients (one of the group with primary AI and four with hypopituitarism) had diabetes mellitus, but only one of them (with hypopituitarism) needed insulin therapy. Tables 1 and 2 summarize the characteristics of the patients enrolled, their comorbidities, previous therapies and the duration of treatment with dual-release hydrocortisone (up to October 2017).

Table 1 Biographical and clinical data of patients with primary adrenal insufficiency.

\begin{tabular}{|c|c|c|c|c|c|c|}
\hline Case no. & Sex & Age (years) & Etiology & Comorbidities & Previous treatment & $\begin{array}{c}\text { Length of } \\
\text { treatment } \\
\text { (months) }\end{array}$ \\
\hline 1 & $\mathrm{M}$ & 23 & $\begin{array}{l}\text { Congenital } \\
\text { adrenal } \\
\text { hyperplasia }\end{array}$ & $\begin{array}{l}\text { Testicular adrenal tumor rest, obesity, } \\
\text { insulin resistance, hyper- } \\
\text { trygliceridemia, blood hypertension }\end{array}$ & Hydrocortisone $30 \mathrm{mg} / \mathrm{day}$ & 20 \\
\hline 2 & $\mathrm{M}$ & 35 & $\begin{array}{l}\text { Autoimmune } \\
\text { adrenalitis }\end{array}$ & None & Prednisone $15 \mathrm{mg} / \mathrm{day}$ & 32 \\
\hline 3 & $\mathrm{~F}$ & 56 & $\begin{array}{l}\text { Autoimmune } \\
\text { adrenalitis }\end{array}$ & $\begin{array}{l}\text { Chronic autoimmune thyroiditis, } \\
\text { premature ovarian failure (POF), } \\
\text { vitamin D deficiency, empty sella } \\
\text { syndrome, obesity, diabetes mellitus }\end{array}$ & Cortisone acetate $37.5 \mathrm{mg} / \mathrm{day}$ & 21 \\
\hline 4 & $\mathrm{M}$ & 20 & $\begin{array}{l}\text { Congenital } \\
\text { adrenal } \\
\text { hyperplasia }\end{array}$ & Testicular adrenal tumor rest, obesity & Hydrocortisone 35 mg/day & 22 \\
\hline 5 & $\mathrm{~F}$ & 39 & $\begin{array}{l}\text { Autoimmune } \\
\text { adrenalitis }\end{array}$ & $\begin{array}{l}\text { Vitiligo, non-secreting pituitary } \\
\text { adenoma, vitamin D deficiency, } \\
\text { chronic autoimmune thyroiditis, } \\
\text { overweight }\end{array}$ & Cortisone acetate $50 \mathrm{mg} / \mathrm{day}$ & 30 \\
\hline 6 & $\mathrm{M}$ & 59 & $\begin{array}{l}\text { Bilateral } \\
\text { surrenectomy }\end{array}$ & Hypogonadism, overweight & Hydrocortisone 40 mg/day & 32 \\
\hline 7 & $\mathrm{M}$ & 20 & $\begin{array}{l}\text { Autoimmune } \\
\text { adrenalitis }\end{array}$ & Vitiligo & Hydrocortisone 32.5 mg/day & 31 \\
\hline 8 & $\mathrm{~F}$ & 69 & $\begin{array}{l}\text { Autoimmune } \\
\text { adrenalitis }\end{array}$ & $\begin{array}{l}\text { Hypertensive cardiopathy, } \\
\text { gastroesophageal reflux, chronic } \\
\text { atrophic gastritis, IgG-lambda } \\
\text { paraproteinemia }\end{array}$ & Cortisone acetate $25 \mathrm{mg} / \mathrm{day}$ & 13 \\
\hline 9 & $\mathrm{M}$ & 50 & $\begin{array}{l}\text { Autoimmune } \\
\text { adrenalitis }\end{array}$ & $\beta$-thalassemia, hypogonadism & None & 11 \\
\hline 10 & $\mathrm{~F}$ & 39 & $\begin{array}{l}\text { Autoimmune } \\
\text { adrenalitis }\end{array}$ & $\begin{array}{l}\text { Vitiligo, chronic autoimmune } \\
\text { thyroiditis }\end{array}$ & None & 7 \\
\hline
\end{tabular}




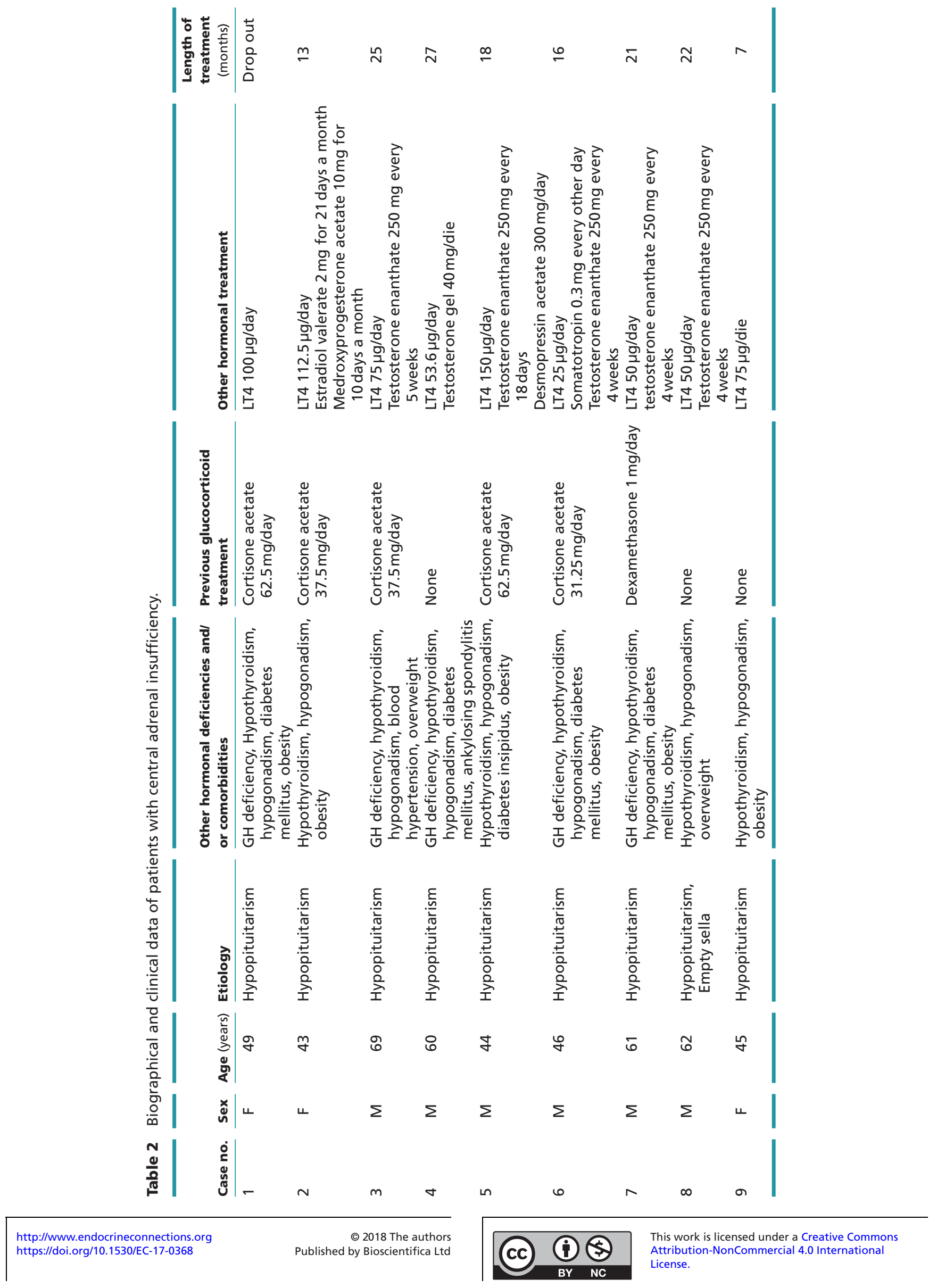


At the moment of the switch, we administered an equivalent dose of dual-release hydrocortisone for the patients who were under replacement therapy, except for three of them, for whom the equivalent dosage was found to be greater than $40 \mathrm{mg} /$ day (maximum dose studied to date) (Table 3). In these 3 cases, the dosage of $40 \mathrm{mg} /$ day was prescribed. Treatment-naïve patients were given $20 \mathrm{mg}$ /day of dual-release hydrocortisone. Each patient received a written document containing instructions for treatment in special or emergency situations. These included major surgery, shock, serious injury, burns, myocardial infarction, minor surgeries (including dental), vomiting and/or diarrhea that lasted for more than a day, high temperature $\left(>38^{\circ} \mathrm{C}\right)$ lasting for more days, moderately stressful procedures (bronchoscopy, endoscopy, barium enema, biopsy under local anesthesia), intense physical and mental stress, intense physical activity and prolonged with sweating (marathons, basketball games or football, mountain hiking, rides cycling, etc.). Finally, each patient was given a card as suggested by the Endocrine Society (10), which identified them as affected by adrenal insufficiency.

Each patient was monitored before being prescribed hydrocortisone dual-release and after 3, 6, 9 and 12 months. The following parameters were evaluated: weight, body mass index (BMI), fasting glucose, insulin (except in the subject into insulin treatment), glycated hemoglobin (HbA1c), total cholesterol, high-density lipoprotein (HDL) and triglycerides. We calculated the homeostasis model assessment (HOMA) index for evaluation of insulin resistance and low density lipoprotein (LDL) to complete the framework for the lipid profile. With the aim of monitoring the therapy and allow appropriate dose adjustments, each patient was asked to collect 24-h urine for the measurement of the urinary free cortisol (UFC). Serum ACTH assessment was required only in patients with primary AI. The blood samples were taken at 8:00 $\mathrm{h}$ and before the dual-release hydrocortisone was taken.

The evaluation of subjective well-being and healthrelated quality of life was evaluated by administering the AddiQol questionnaire at each visit. It consists of 30 questions divided into the four different domains: 8 questions exploring fatigue (items 1, 2, 3, 4, 5, 23, 26, 27); 8 questions the emotional sphere (items 11, 12, 13, 14, 15, 24, 25, 30); 9 questions AI symptoms (items 6, 9, 16, 17, $18,19,20,21,22)$ and 5 miscellaneous questions, which explore sleep (items 7, 8), sexuality (item 10) and the impact of intercurrent diseases (items 28, 29).

\section{Statistical analysis}

The results are reported as mean \pm s.E.M. Statistical analysis of the data was performed using Student's $t$ test. The results with a $P$ value less than 0.05 were considered statistically significant.

Table 3 Previous treatment, equivalent dosage of hydrocortisone dual-release and its current dosage administered.

\begin{tabular}{|c|c|}
\hline Case no. & Previous treatment (dosage) \\
\hline 1 & Hydrocortisone (30 mg/day) \\
\hline 2 & Prednisone (15 mg/day) \\
\hline 3 & Cortisone acetate ( $37.5 \mathrm{mg} /$ day) \\
\hline 4 & Hydrocortisone (35 mg/day) \\
\hline 5 & Cortisone acetate ( $50 \mathrm{mg} /$ day) \\
\hline 6 & Hydrocortisone (40 mg/day) \\
\hline 7 & Hydrocortisone (32.5 mg/day) \\
\hline 8 & Cortisone acetate ( $25 \mathrm{mg} /$ day $)$ \\
\hline 9 & None \\
\hline 10 & None \\
\hline 11 & Cortisone acetate ( $62.5 \mathrm{mg} /$ day) \\
\hline 12 & Cortisone acetate $(37.5 \mathrm{mg} /$ day $)$ \\
\hline 13 & Cortisone acetate ( $37.5 \mathrm{mg} /$ day) \\
\hline 14 & None \\
\hline 15 & Cortisone acetate (62.5 mg/day) \\
\hline 16 & Cortisone acetate (31.25 mg/day) \\
\hline 17 & Dexamethasone (1 mg/day) \\
\hline 18 & None \\
\hline 19 & None \\
\hline Mean \pm S.E.M. & \\
\hline
\end{tabular}

\begin{tabular}{c}
$\begin{array}{c}\text { Equivalent hydrocortisone dosage } \\
\text { (mg/day) }\end{array}$ \\
\hline 30 \\
60 \\
30 \\
35 \\
40 \\
40 \\
32.5 \\
20 \\
None \\
None \\
50 \\
30 \\
30 \\
None \\
50 \\
25 \\
30 \\
None \\
None \\
\end{tabular}

\begin{tabular}{c}
$\begin{array}{c}\text { Total dosage prescribed } \\
\text { (mg/day) }\end{array}$ \\
\hline 30 \\
40 \\
30 \\
35 \\
40 \\
40 \\
30 \\
20 \\
20 \\
20 \\
40 \\
30 \\
30 \\
20 \\
40 \\
25 \\
30 \\
20 \\
20 \\
$30.0 \pm 7.1$
\end{tabular}

\begin{tabular}{c}
$\begin{array}{c}\text { Current dosage } \\
\text { (mg/day) }\end{array}$ \\
\hline 25 \\
35 \\
30 \\
35 \\
30 \\
35 \\
30 \\
20 \\
20 \\
20 \\
Drop out \\
25 \\
15 \\
20 \\
40 \\
20 \\
20 \\
20 \\
20 \\
$24.71 \pm 5.82$
\end{tabular}

http://www.endocrineconnections.org https://doi.org/10.1530/EC-17-0368 (c) 2018 The authors Published by Bioscientifica Ltd

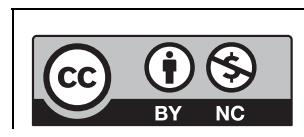

This work is licensed under a Creative Commons Attribution-NonCommercial 4.0 International License. 


\section{Results}

A female patient with hypopituitarism dropped out from the study for personal reasons; she was among the patients who were prescribed $40 \mathrm{mg}$ /day of dual-release hydrocortisone, although the calculated equivalent dosage was $50 \mathrm{mg} /$ day (Table 3, patient 11). As far as the other patients, 15 of them (8 with primary AI and 7 with hypopituitarism) are under treatment for more than 12 months with hydrocortisone dual-release. Overall, the mean length of treatment is $20.4 \pm 1.91$ months (range 1-32 months) (up to October 2017) (Tables 1 and 2).

Patients who were previously treated with synthetic glucocorticoids (prednisone and dexamethasone) did not complain of any symptoms during the therapy switch.

At enrollment, patients with primary AI had lower BMI compared to those with hypopituitarism, but the difference did not reach the statistical significance. After 12 months of treatment, BMI did not change significantly in both groups of patients compared to their basal values (Fig. 1).

No significant change was observed in blood fasting glucose, serum insulin levels and HOMA index after 12 months of treatment with dual-release hydrocortisone compared to basal values in both groups of patients. On the other hand, HbA1c decreased in a statistically significant manner $(P<0.05)$ after 12 months of treatment in patients with primary $\mathrm{AI}$, whereas no statistically significant difference was found in hypopituitary patients (Fig. 2).

We evaluated separately blood glucose and HbA1c values of the 5 diabetic patients. To date (October 2017), among these, one dropped out the study, the other 4 have exceeded 12 months of treatment with dual-release hydrocortisone. During these months, no significant

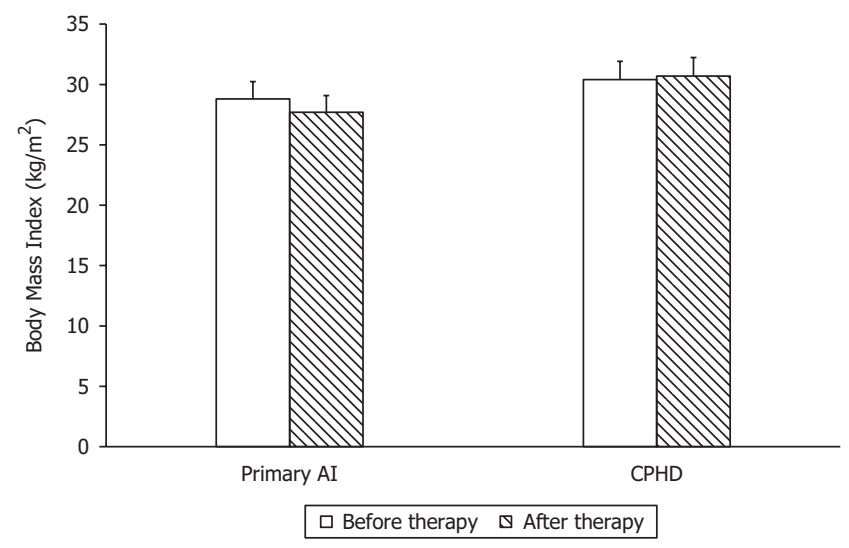

Figure 1

Body mass index in patients with primary adrenal insufficiency (AI) or hypopituitarism before and after 12 months of treatment with hydrocortisone dual-release.

http://www.endocrineconnections.org https://doi.org/10.1530/EC-17-0368

(C) 2018 The author Published by Bioscientifica Ltd changes in glycometabolic control, insulin and/or oral hypoglycemic agents daily dosage occurred.

No significant change was observed in plasma levels of total cholesterol, LDL, HDL and triglycerides after 12 months of treatment with dual-release hydrocortisone compared to basal values in both groups of patients (Fig. 3). Interestingly, mean triglyceride values were lower in patients with primary AI after 12 month of therapy, whereas it was higher in hypopituitarism patients. This resulted in a statistically significant difference in plasma triglyceride values between the two groups of patients $(P<0.05)$ (Fig. 3).

The ACTH values, analyzed only in patients with primary disease, also appeared lower than the baseline value, but the difference did not reach the statistical significance. The serum levels of $17 \alpha$-hydroxyprogesterone did not differ significantly from baseline after dualrelease hydrocortisone treatment in the two patients with congenital adrenal hyperplasia.

As for the evaluation of the subjective well-being, nine patients reported discomfort and fatigue before starting treatment with dual-release hydrocortisone. All patients, even those who had not complained about relevant disturbances, reported an improvement of their well-being compared to that they had before the initiation of the treatment with dual-release hydrocortisone. This improvement was already evident after three months of treatment. Accordingly, the scores obtained by filling out the AddiQol questionnaire showed a condition of well-being, which was maintained over time even after 12 months of treatment (Fig. 4).

No patient reported side effects or intercurrent diseases, and the therapy compliance was optimal for all of them.

Finally, it is interesting to highlight that considering all the patients enrolled in the study, over the months, there was a statistically significant decrease $(P<0.05)$ of the mean dosage of glucocorticoid required (Table 3 ). Dose adjustment was made taking into account 24-h free urinary cortisol values. For all the naïve patients, the starting dosage of $20 \mathrm{mg}$ /die of dual-release hydrocortisone was maintained unchanged throughout the study.

\section{Discussion}

The treatment for AI has undergone a major change since a new formulation of dual-release hydrocortisone has been developed. If the previous treatment, mainly based on the use of cortisone acetate or hydrocortisone,

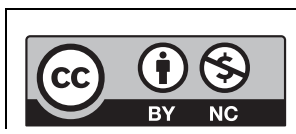

This work is licensed under a Creative Commons Attribution-NonCommercial 4.0 International License. 

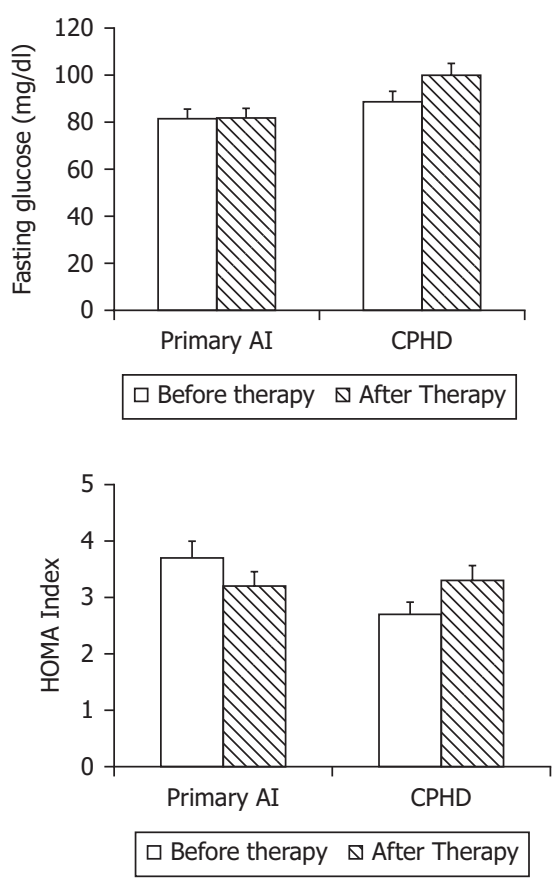
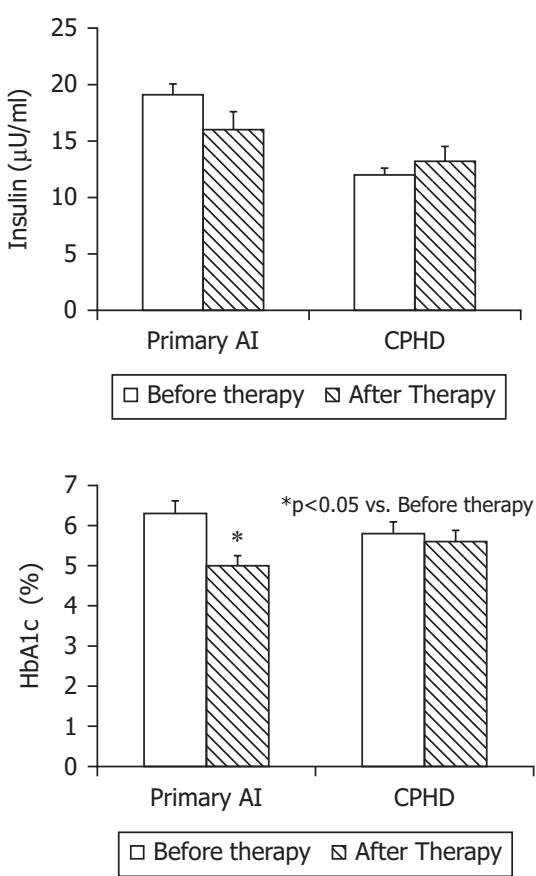

Figure 2

Fasting glucose, serum insulin levels, HOMA index and $\mathrm{HbA1c}$ levels in patients with primary adrenal insufficiency (Al) or hypopituitarism before and after 12 months of treatment with hydrocortisone dual-release. required repeated (two or three) daily administrations, the double-release formulation requires once-daily dosing, thus improving the compliance and allowing a more physiological mimicking of cortisol secretion circadian rhythm (11). Indeed, the administration of glucocorticoids several times a day exposes patients to supraphysiological cortisol peaks, which affect the health status of patients with AI negatively. Therefore, dual-release hydrocortisone should reduce, at least in part, the limitations related to conventional glucocorticoid treatment: premature mortality (3), high frequency of hospitalization for intercurrent illnesses, especially infections $(3,12)$, quality of life impairment (13), poor glycometabolic control (6) and decreased bone mineral density (BMD) (14). Dualrelease hydrocortisone maintains constant levels of cortisol during the 24-h avoiding overtreatment. Indeed, after oral intake, already after $20 \mathrm{~min}$, there is an increase in serum cortisol levels, while the maximum concentration
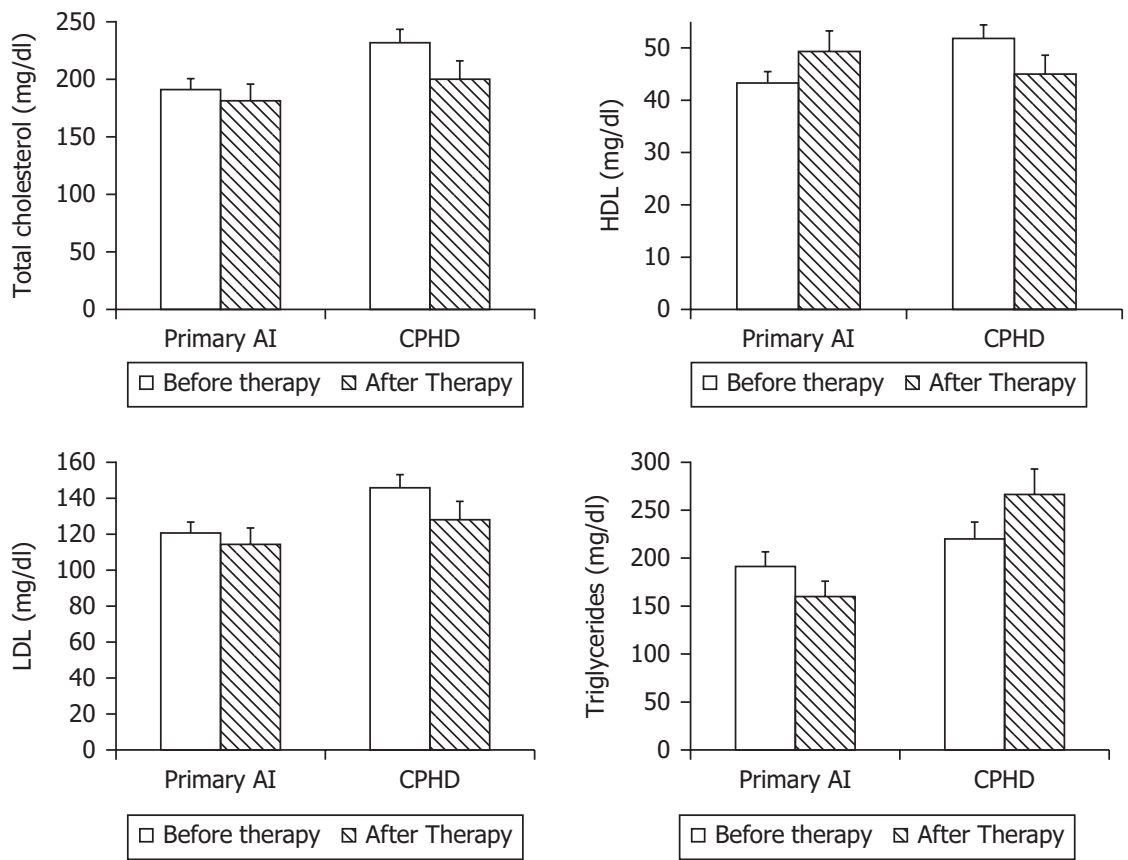

Figure 3

Total cholesterol, HDL, LDL and triglycerides levels in patients with primary adrenal insufficiency (Al) or hypopituitarism before and after 12 months of treatment with hydrocortisone dual-release. Mean triglyceride value was lower in patients with primary Al after 12 months of therapy, whereas it was higher in the group of patients with hypopituitarism. This resulted in a statistically significant difference in plasma triglyceride values between the two groups of patients $(P<0.05)$

$$
\begin{array}{lr}
\text { http://www.endocrineconnections.org } & \odot 2018 \text { The authors } \\
\text { https://doi.org/10.1530/EC-17-0368 } & \text { Published by Bioscientifica Ltd }
\end{array}
$$



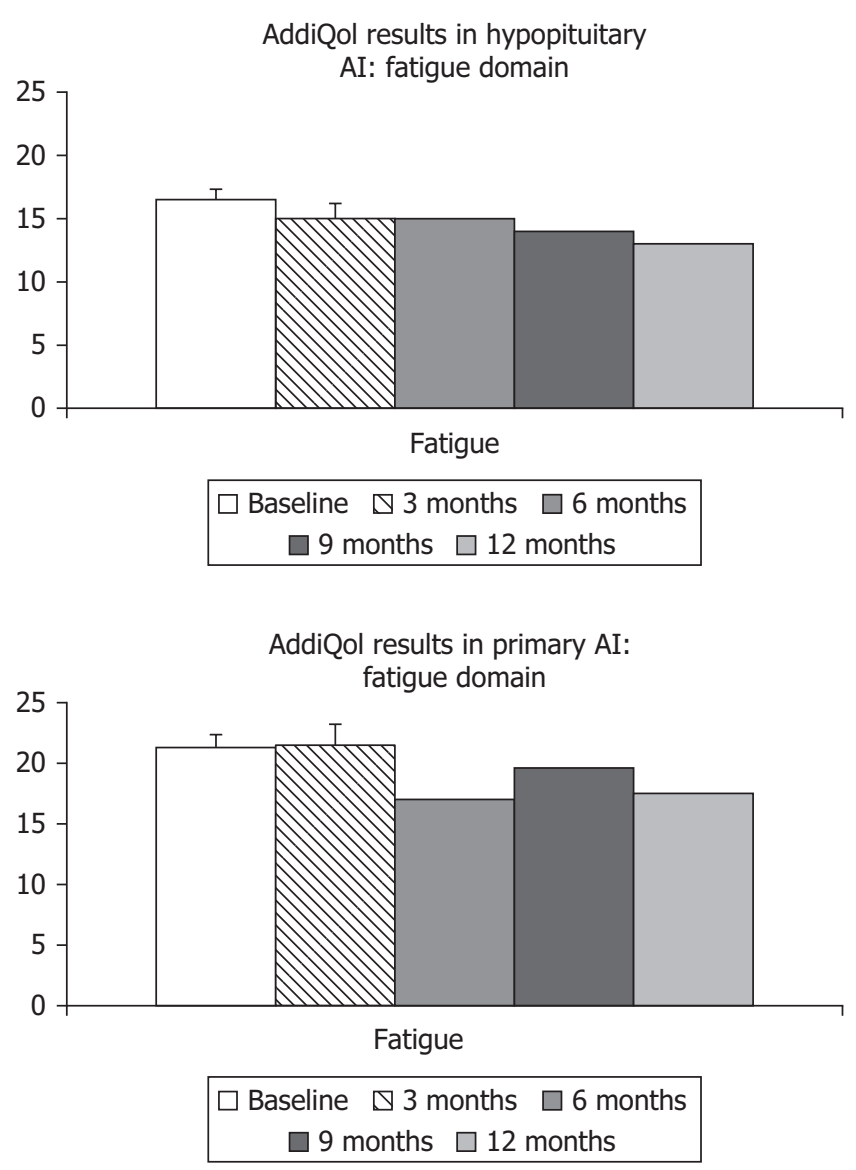

Figure 4

AddiQol fatigue domain results.

(188 nmol/L for $5 \mathrm{mg}$ tablet and $403 \mathrm{nmol} / \mathrm{L}$ for $20 \mathrm{mg}$ tablet) is reached after $40-50 \mathrm{~min}$ (15). Moreover, even after $18-24 \mathrm{~h}$ after administration, plasma concentrations of cortisol appear to be higher than $50 \mathrm{nmol} / \mathrm{L}$, without accumulation of the drug (15).

Since the commercial introduction of dual-release hydrocortisone is relatively recent, very few studies have explored its efficacy. Johannsson and coworkers conducted a multicenter randomized controlled study on 64 patients with $\mathrm{AI}$, with the aim of comparing the profile of serum cortisol exposure in patients under hydrocortisone replacement therapy administered 3 times/day, compared to patients treated with dualrelease hydrocortisone once-daily for 3 months (11). At the end of the 3 months, dual-release hydrocortisone mimicked the physiological circadian rhythm of cortisol secretion, confirming the results these authors had previously published in a phase 1 study (9). Moreover, the authors also found a significant decrease in body weight, blood pressure and an improvement in glucose metabolism (11).

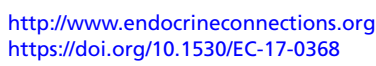

C) 2018 The authors Published by Bioscientifica Ltd
Quinkler and coworkers conducted an open, prospective trial to compare dual-release hydrocortisone therapy with conventional hydrocortisone treatment on clinical parameters and quality of life (16). The authors concluded that dual-release hydrocortisone administration decreased BMI and HbA1c compared with conventional treatment, and it stabilized health-related quality of life (16).

More recently, Giordano and coworkers conducted a study on 19 patients with Addison's disease, previously treated with hydrocortisone $20 \mathrm{mg}$ administered 3 times a day (17). At the end of the observation period, the waist circumference of the patients was found to be significantly lower than that at the beginning of the treatment. HbA1c, total and LDL cholesterol after 12 months were statistically significant lower compared to the baseline (17). Finally, ACTH values decreased significantly after 6 months of treatment (17).

The present study for the first time analyzed the effects of dual-release hydrocortisone treatment also in patients naïve for therapy. Our results did not show statistically significant differences of the examined parameters after 12 months of treatment with dual-release hydrocortisone in both groups of patients, except for HbA1c, which was significantly lower in patients with primary AI. Moreover, in the group of subjects with hypopituitarism, the glycometabolic profile and the triglycerides blood levels appeared worse after 12 months of treatment with dual-release hydrocortisone. Biochemical indices are fundamental for monitoring glucocorticoid replacement therapy and its dosage adjustments, but the subjective well-being remains the main parameter to be evaluated in patients with AI. For this purpose, a questionnaire was developed to 'measure' the disease-related symptoms and the degree of interference of the latter in the every-day life of patients with AI. The use of these questionnaires is not unusual in endocrinology. Over the years, in fact, several questionnaires have been developed to measure the quality of life related to specific health conditions for some diseases (disease-specific health-related quality of life, HRQoL): GH deficiency (Assessment of Growth Hormone Deficiency in Adults, AGHDA) (18), acromegaly (Acromegaly Quality of Life questionnaire, AcroQoL) and Cushing's syndrome (Cushing Quality of Life questionnaire, CushingQoL) (19). Along the lines of the latter, in 2010 Løvås and collaborators created a specific HRQoL questionnaire for the evaluation of patients with Addison's disease and, more generally, AI replacement therapy (AddiQol) (20). At first the questionnaire consisted of 36 questions, some adapted from other questionnaires

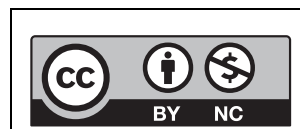

This work is licensed under a Creative Commons Attribution-NonCommercial 4.0 International License. 
and other of new formulation (20). The questionnaire was then validated in 2012 (21), and in its final form, the AddiQol questionnaire consists of 30 questions.

In the present study, we administered the AddiQol questionnaire to all patients before to be switched to dual-release hydrocortisone and after 3, 6, 9 and 12 months of treatment. All patients, even those who did not complain particular symptomatology during the previous treatment, reported an improvement in the clinical condition and subjective well-being after 3 months of treatment with the new formulation of hydrocortisone; this outcome was also maintained for the subsequent months. Furthermore, all patients have shown a good compliance to therapy.

As regard to possible adverse reactions and side effects, Nilsson and coworkers conducted a study on 64 patients with AI (other 16 individuals were added later), to evaluate long-term clinical safety ( 24 months) of treatment with dual-release hydrocortisone (22). This study showed that within the first 3 months of treatment, the rate of adverse effects was similar among patients treated with the new formulation vs patients receiving hydrocortisone in three daily administrations (73.4\% vs $65.6 \%$ ), while it decreased in the subsequent months. In addition, although both groups of patients received an equivalent dose of hydrocortisone, the total exposure to cortisol was lower than the $19.4 \%$ in patients taking dual-release hydrocortisone compared to those who were treated with hydrocortisone in three daily doses. The authors concluded that long-term treatment with the new formulation of hydrocortisone appeared to be safe, well tolerated and effective, allowing even a slight reduction in body weight and without causing a deterioration of the pressure profile and glucose metabolism (22). Accordingly, no patient enrolled in the present study reported adverse effects worthy of note, and there were no comorbidities during the period of observation.

Finally, it is important to say that no studies have evaluated the effects of dual-release hydrocortisone at a posology greater than $40 \mathrm{mg} /$ day. Our study allowed us to observe how the dose of $40 \mathrm{mg}$ /day was sufficient to obtain good clinical and biochemical compensation in patients for whom the equivalent dose of the drug exceeded this limit. In addition, after 12 months of treatment, the average daily dose of drug administered $(25.9 \pm 6.1 \mathrm{mg} /$ day $)$ appears to be significantly lower $(P<0.05)$ compared to the initial dose $(30 \pm 7.07 \mathrm{mg} /$ day $)$ (Table 3). To our knowledge, currently, no other study in literature has reported similar data.

\section{Conclusions}

Dual-release hydrocortisone represents a breakthrough in the replacement glucocorticoid treatment in patients with AI. The results of this study showed an improvement in the glycometabolic profile of patients with primary AI. Moreover, this formulation, taken once-daily, is effective in improving treatment compliance and subjective wellbeing of patients. Finally, we found no side effects or adverse reactions worthy of note; therefore, the product is also safe from the clinical point of view. In conclusion, dual-release hydrocortisone seems to be an effective and valuable therapeutic strategy for the treatment of patients with AI.

\section{Declaration of interest}

The authors declare that there is no conflict of interest that could be perceived as prejudicing the impartiality of the research reported.

\section{Funding}

This research did not receive any specific grant from any funding agency in the public, commercial or not-for-profit sector.

\section{References}

1 Bensing S, Hulting AL, Husebye ES, Kämpe O \& Løvås K. Management of endocrine disease: epidemiology, quality of life and complications of primary adrenal insufficiency: a review. European Journal of Endocrinology 20163 R107-R116. (https://doi.org/10.1530/ EJE-15-1242)

2 Arlt W \& Allolio B. Adrenal insufficiency. Lancet 2003361 1881-1893. (https://doi.org/10.1016/S0140-6736(03)13492-7)

3 Bergthorsdottir R, Leonsson-Zachrisson M, Odén A \& Johannsson G. Premature mortality in patients with Addison's disease: a populationbased study. Journal of Clinical Endocrinology and Metabolism $2006 \mathbf{9 1}$ 4849-4853. (https://doi.org/10.1210/jc.2006-0076)

4 Ross IL, Bergthorsdottir R, Levitt NS, Schatz DA, Johannsson G \& Marais AD. Increased cardiovascular risk in South African patients with Addison's disease. Hormone and Metabolic Research 201345 905-910. (https://doi.org/10.1055/s-0033-1351259)

5 Ross IL, Bergthorsdottir R, Levitt N, Dave JA, Schatz D, Marais D \& Johannsson G. Cardiovascular risk factors in patients with Addison's disease: a comparative study of South African and Swedish patients. PLOS ONE 20149 e90768. (https://doi.org/10.1371/journal. pone.0090768)

6 Filipsson H, Monson JP, Koltowska-Häggström M, Mattsson A \& Johannsson G. The impact of glucocorticoid replacement regimens on metabolic outcome and comorbidity in hypopituitary patients. Journal of Clinical Endocrinology and Metabolism 200691 3954-3961. (https://doi.org/10.1210/jc.2006-0524)

7 Giordano R, Marzotti S, Balbo M, Romagnoli S, Marinazzo E, Berardelli R, Migliaretti G, Benso A, Falorni A, Ghigo E, et al. Metabolic and cardiovascular profile in patients with Addison's disease under conventional glucocorticoid replacement. Journal of Endocrinological Investigation 200932 917-923. (https://doi. org/10.3275/6437)

8 Husebye ES, Allolio B, Arlt W, Badenhoop K, Bensing S, Betterle C, Falorni A, Gan EH, Hulting AL, Kasperlik-Zaluska A, et al. Consensus

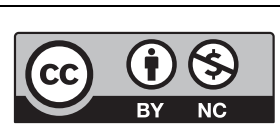

This work is licensed under a Creative Commons Attribution-NonCommercial 4.0 International License. 
statement on the diagnosis, treatment and follow-up of patients with primary adrenal insufficiency. Journal of Internal Medicine 2014275 104-115. (https://doi.org/10.1111/joim)

9 Johannsson G, Bergthorsdottir R, Nilsson AG, Lennernas H, Hedner T $\&$ Skrtic S. Improving glucocorticoid replacement therapy using a novel modified-release hydrocortisone tablet: a pharmacokinetic study. European Journal of Endocrinology 2009161 119-130. (https:// doi.org/10.1530/EJE-09-0170)

10 Bornstein SR, Allolio B, Arlt W, Barthel A, Don-Wauchope A, Hammer GD, Husebye ES, Merke DP, Murad MH, Stratakis CA, et al. Diagnosis and treatment of primary adrenal insufficiency: an Endocrine Society clinical practice guideline. Journal of Clinical Endocrinology and Metabolism 2016101 364-389. (https://doi. org/10.1210/jc.2015-1710)

11 Johannsson G, Nilsson AG, Bergthorsdottir R, Burman P, Dahlqvist P, Ekman B, Engström BE, Olsson T, Ragnarsson O, Ryberg M, et al. Improved cortisol exposure-time profile and outcome in patients with adrenal insufficiency: a prospective randomized trial of a novel hydrocortisone dual-release formulation. Journal of Clinical Endocrinology and Metabolism 201297 473-481. (https://doi. org/10.1210/jc.2011-1926)

12 Hahner S, Loeffler M, Bleicken B, Drechsler C, Milovanovic D, Fassnacht M, Ventz M, Quinkler M \& Allolio B. Epidemiology of adrenal crisis in chronic adrenal insufficiency: the need for new prevention strategies. European Journal of Endocrinology 2010162 597-602. (https://doi.org/10.1530/EJE-09-0884)

13 Hahner S, Loeffler M, Fassnacht M, Weismann D, Koschker AC, Quinkler M, Decker O, Arlt W \& Allolio B. Impaired subjective health status in 256 patients with adrenal insufficiency on standard therapy based on cross-sectional analysis. Journal of Clinical Endocrinology and Metabolism 200792 3912-3922. (https://doi.org/10.1210/jc.20070685)

14 Løvås K, Curran S, Oksnes M, Husebye ES, Huppert FA \& Chatterjee VK. Development of a disease-specific quality of life questionnaire in Addison's disease. Journal of Clinical Endocrinology and Metabolism 201095 545-551. (https://doi.org/10.1210/jc.20091711)

15 Reznik Y. Therapeutic innovations in endocrine diseases - part 2: modified-release glucocorticoid compounds: what good do they provide to the adrenal insufficient patient? La Presse Médicale 2016 45 e205-e210. (https://doi.org/10.1016/j.lpm.2016.05.007)

16 Quinkler M, Miodini Nilsen R, Zopf K, Ventz M \& Øksnes M. Modifiedrelease hydrocortisone decreases BMI and HbA1c in patients with primary and secondary adrenal insufficiency. European Journal of Endocrinology 2015172 619-626. (https://doi.org/10.1530/EJE-14-1114)

17 Giordano R, Guaraldi F, Marinazzo E, Fumarola F, Rampino A, Berardelli R, Karamouzis I, Lucchiari M, Manetta T, Mengozzi G, et al. Improvement of anthropometric and metabolic parameters, and quality of life following treatment with dual-release hydrocortisone in patients with Addison's disease. Endocrine 201651 360-368. (https://doi.org/10.1007/s12020-015-0681-z)

18 Webb SM, Prieto L, Badia X, Albareda M, Catalá M, Gaztambide S, Lucas T, Páramo C, Picó A, Lucas A, et al. Acromegaly Quality of Life Questionnaire (ACROQOL) a new health-related quality of life questionnaire for patients with acromegaly: development and psychometric properties. Clinical Endocrinology 200257 251-258. (https://doi.org/10.1046/j.1365-2265.2002.01597.x)

19 Webb SM, Badia X, Barahona MJ, Colao A, Strasburger CJ, Tabarin A, van Aken MO, Pivonello R, Stalla G, Lamberts SW, et al. Evaluation of health-related quality of life in patients with Cushing's syndrome with a new questionnaire. European Journal of Endocrinology $2008 \mathbf{1 5 8}$ 623-630. (https://doi.org/10.1530/EJE-07-0762)

20 Løvås K, Gjesdal CG, Christensen M, Wolff AB, Almås B, Svartberg J, Fougner KJ, Syversen U, Bollerslev J, Falch JA, et al. Glucocorticoid replacement therapy and pharmacogenetics in Addison's disease: effects on bone. European Journal of Endocrinology 2009160 993-1002. (https://doi.org/10.1530/EJE-08-0880)

21 Øksnes M, Bensing S, Hulting AL, Kämpe O, Hackemann A, Meyer G, Badenhoop K, Betterle C, Parolo A, Giordano R, et al. Quality of life in European patients with Addison's disease: validity of the diseasespecific questionnaire AddiQoL. Journal of Clinical Endocrinology and Metabolism 201297 568-576. (https://doi.org/10.1210/jc.2011-1901)

22 Nilsson AG, Marelli C, Fitts D, Bergthorsdottir R, Burman P, Dahlqvist P, Ekman B, Engström BE, Olsson T, Ragnarsson O, et al. Prospective evaluation of long-term safety of dual-release hydrocortisone replacement administered once daily in patients with adrenal insufficiency. European Journal of Endocrinology 2014171 369-377. (https://doi.org/10.1530/EJE-14-0327)

Received in final form 6 December 2017

Accepted 12 December 2017

Accepted Preprint published online 12 December 2017 http://www.endocrineconnections.org https://doi.org/10.1530/EC-17-0368
() 2018 The authors Published by Bioscientifica Ltd

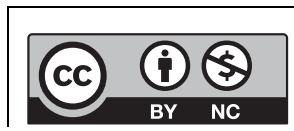

This work is licensed under a Creative Commons Attribution-NonCommercial 4.0 International License. 